\title{
Recreating Draupadi: A Study of Chitra Banerjee Divakaruni's The Palace of Illusions
}

\author{
Prerona Bora \\ Ph.D. Research Scholar \\ Department of English \\ Mahapurusha Srimanta Sankaradeva Viswavidyalaya \\ Nagaon, Assam, India \\ boraprerona9@gmail.com
}

Abstract

Mythological retellings have explored those issues of the epics which were submerged in the objective representation of the events. Redefining the existence of the epical characters, these revisionist writings have presented the events from the alternate perspectives. With an attempt to deconstruct the concept of 'truth', the contemporary mythological retellings have tried to demystify the dominant ideologies, and for this purpose they had brought into forefront the overlooked characters. In the grand narrative of the epics like the Ramayana and the Mahabharata the perspectives of the women characters were often overlooked; at the same time the objective representation of the events could not provide the necessary space to delve deep into their psyche. Therefore, ample numbers of the contemporary mythological retellings have highlighted the lives of the women characters of the epics, by presenting the events from their perspectives to explore those facets of the 'truth' which were overlooked in the source texts. This research article has attempted to reconstruct the identity of Draupadi of the Mahabharata by focusing on her character as depicted by Chitra Banerjee Divakaruni in her The Palace of Illusions, a wonderful mythological fiction reinterpreting the events of the epic Mahabharata from Draupadi's perspective. Adopting a feminist stance, this research 
article has explored Draupadi's resistance to patriarchal domination, and in this way, here an attempt has been undertaken to reassert her individuality and to redetermine her role in the epic.

Keywords: Retelling, Myth, Feminism, Patriarchy, Ideology, Subjugation Introduction:

Feminism itself is known as a kind of constructive deconstruction, which attempts to relocate the lost identities of women. As a literary movement feminism can be said to have flourished with Mary Wollstonecraft's A Vindication of the Rights of Women (1792). Gradually a number of great feminist texts have emerged, claiming the necessity to reclaim their own identity, as a revolt against the patriarchal domination. Some of the revolutionary feminist texts are, Simone De Beauvoir's The Second Sex (1952), Virginia Woolf's A Room of One's Own (1929), Betty Friedan's The Feminine Mystique(1963) and Kate Millet's Sexual Politics (1970). Therefore, in order to demystify the patriarchal hegemony, Helen Cixous felt the necessity of the emergence of women's writing in order to portray the life of women from a woman's perspective, Cixous said, "Woman must write herself; must write about women and bring women to writing, women must put herself into the text- as into the world and into history by her own movement" ( $\mathrm{p}$ 254). Adopting a feminist perspective, contemporary women writers like Pratibha Rai, Saoli Mitra, Chitra Banerjee Divakaruni, Madhavi S Mahadevan, Aditi Banerjee, Manini J Anandani have greatly contributed in the field of women's writings by revisiting the epics from women's perspective. Their revisionist writings have rescued the women characters from the objective and stereotypical representations of the epics.

In the development of Indian culture and in defining Indian tradition mythological writings have greatly contributed. Myths have elucidated morality and determined the purpose of human life. Guiding the mind and the actions of human beings Indian epics like 
the Ramayana and the Mahabharata had glorified the victory of integrity and justice. But amidst such glorifications the epics were not able to present an in-depth study of the life of all the important characters. Whereas the Ramayana was known as the legend of lord Rama, the Mahabharata had glorified the valor and chivalry of the Pandavas. Therefore, epics can be defined as the tale of the victorious class, and mainly about the life of men, where the perspectives of the women characters were never presented. In the epics the women characters had got their identity based on their relation with men. They were presented as daughters, wives, daughters-in-law and mothers and all these identities in relation to others they had lost their real identities, "She is determined and differentiated in relation to man, while he is not in relation to her; she is the inessential in front of the essential. He is the subject; he is the absolute. She is the other" (Beauvoir 6). Simon De Beauvoir, in her the Second Sex had rightly quoted a seventeenth-century feminist, who said, "Everything that men have written about women should be viewed with suspicion, because they are both judge and party" ( $\mathrm{p} 10)$. And the epics as the creation of men's mind presenting men's perspective justifies the need to revisit the epics from the perspectives of women to determine how much the women characters were victimized in the source texts.

Analysis

Chitra Banerjee Divakaruni in her The Palace of Illusions, deconstructed the long prevailing identity of Draupadi by exploring her voice and by redetermining her existence in the epics. Her plight was determined at the time of her birth when she was named after her father Draupad, because, with this name she had lost her identity as her identity was defined by the name of her father. And in this way, her name had already foretold her predicament in the male dominated society. Therefore, in order to define women's position in the patriarchal society, Beauvoir said, "She is determined and differentiated in relation to man, while he is not in relation to her; she is the inessential in front of essential. He is the subject; he is the 
absolute. She is the other" (p06). Deep down inside, Draupadi had never accepted her name, because she knew that she was capable of forming her own identity, and she didn't want the support of her father's name to define her dignity. Divakaruni's Draupadi was not silent and submissive, she could not accept all prevailing beliefs blindly and she had never allowed the patriarchal hegemony to overpower her own conscience. Throughout her life, Draupadi had to face endless sufferings and humiliations, but she had turned all these adversities, into the opportunities to prove her indomitable spirit and that was the reason she emerged as the woman of iron will who had changed the course of history.

Delving deep into her mind and feelings, Divakaruni had very beautifully portrayed the reasons behind her choices and actions. Draupadi had witnessed the prevailing gender discrimination when she was a little child and she herself had become its victim. From her Dhai ma, Draupadi came to know that she was an unwelcomed child. King Draupad her father wanted only a son, to avenge his humiliation and a girl child was of no use for him. Draupadi during her childhood days, on a number of occasions had perceived her father's favoritism towards her brother Dhristadyumna. By facing such discrimination in that little age Draupadi had not only lost her faith in her father but at the same time she became aware of prevailing gender prejudices of her time. This loss of faith in her father played an important role in fueling her rebellious attitude towards such injustices. Her self-respect had refrained her from accepting her father's palace as her 'home', because, she could never forget about his initial rejection of her. Therefore, she had a dream of her own home, which would belong to her in its true sense, she said, "I only knew that it would mirror my deepest being. There I would finally be at home" (Divakaruni 7). Draupadi's search for home can be called as the reflection of her eternal journey towards her own emancipation. Though her father's biased attitude hurt her, but the magical story of her birth provided her the desired satisfaction and solace. The story of her mystical birth offered her the opportunity to oppose 
the prejudices regarding women's identity, and in this way, she got some space to assert her own individuality and to admire her own uniqueness. Draupadi was not like her brother Dhri, who always tried to find out ways to admire their father, but Draupadi knew that covering the faults would do nothing good, and therefore she told Dhri, "You're always trying to make him good, pretending he wasn't at fault" (Divakaruni 16). She questioned her brother's blind support to their father, king Draupad,she asked him, “Aren't you giving up your entire life to get king Draupad what he wants—senseless though it is?” (Divakaruni 19).

Draupadi knew very well that women's emancipation could be brought through their self-esteem and it was only proper education which could improve their position by their intellectual development. Draupadi had to face great opposition when she expressed her desire to study with her brother. But at that time in their royal family, girls were not offered the same kind of education as that of the boys. Everyone in the palace had opposed her education and even her Dhai ma who had always supported her, was against it, and Dhai ma didn't prefer such education for her, because, Draupadi said, "She complained that they were making me too hardheaded and argumentative, too manlike in my speech"(Divakaruni 23).Draupadi dared to question the illogical and baseless prejudices regarding women's identity, when Draupadi's tutor said, “women are the path to ruin"(Divakaruni 24), then Draupadi could not remain silent, and in return she said, “Additionally, I resented the tutor's declaration that women were the root of all the world's trouble"(Divakaruni 24).She protested against such stern words from the tutor, by simply with her smiles, and her smile had done what she wanted to see. "Perhaps that was why, when he gathered up his palm leaf manuscripts and rose to leave, I pushed the curtain aside and gave him a brilliant smile as I bowed. The effect was better than I hoped. He jumped as though stung; manuscript fell, helter-skelter, from his hands" (Divakaruni 24-25). Through this act of revolt, for the first time she could feel her own will power and she said, "But inside a current surged through me 
at the discovery of a power I didn't know I had" (Divakaruni25). Mary Wollstonecraft defined the lack of education as the ultimate reason behind women's sufferings, and therefore she gave emphasis on women's education so that, they can act as companions to their husbands, because only equality can rescue them from their existence as 'the other' of the society.The patriarchal society has never encouraged women's education, because, women's education could reverse their plane of domination and the male dominated society prefers those kinds of teachings for women, which can secure their own superiority, by confining women within the category of 'other'. And the patriarchal hegemony compelled women to accept the conspired policy of education without any opposition. But Divakaruni's Draupadi was not satisfied with the teachings for women, and she said, "I was better at composing and solving riddles, responding to witty remarks, and writing poetry, but myheart was not in such frivolities. With each lesson I felt the world of women tightening its noose around me" (p 29).That is why, Judith Butler said about the 'performativity of gender', which implies that gender is constructed through the process of internalizing gender conventions, since, no one possesses any definite code of conduct from his or her birth; both men and women are compelled to acquire and adopt such conventions to live in the society. But, Draupadi's free will had never allowed her to follow any illogical prejudices, as she knew her emancipation relied on her competency and her firmness. Therefore, Draupadi preferred that type of education which would help her in fulfilling the purpose of her life.

Draupadi knew very well that her marriage with Arjun was planned only as a kind of political alliance, and as a daughter she had supported what her father had accepted from her,but for that purpose she had insulted Karna, which became the reason of her later repentance. Draupadi had done what she could, so that her father's plan could succeed. Kunti advised all her sons to marry Draupadi, and later on Draupadi also understood the underlying motive of Kunti behind such an act, and that was to bind her sons forever, and Draupadi was 
used as the 'thread' for this purpose. Draupadi herself felt the necessity of such a unity among them, as she said, "They would have pursued separate interests, deposited their loyalties with different women. But together, we formed something precious and unique" (Divakaruni 152). As a wife, Draupadi had never ignored her duties and responsibilities, and she tried to fulfill all their expectations from her. With her strong determination, Draupadi had overcome all the adversities of such a marriage, which she had never imagined. Draupadi again said, "I finally began to see what the willy Kunti had in her mind when she insisted that I was to be married to all of them, and though they never made my heart beat widely, the way I'd hoped as a girl, I committed myself totally to the welfare of the Pandavas" (Divakaruni 152). Draupadi knew very well that, whereas acceptance, mutual understanding and compassion could be the base of a happy married life, in the same way, dissatisfaction and resentments would bring only disappointments and difficulties. Therefore, forgetting everything what she got from her marriage, she had tried to find out the way to peace, Draupadi said, "I saw my husband too differently. They were a unit together, five fingers that complemented each other to make up a powerful hand - a hand that would protect me if the need arose. A hand that had gifted me this beautiful palace. Wasn't that sufficient to be thankful for?" (Divakaruni 148).

It is true that as a wife, Draupadi's life and all her efforts were for the peace and wellbeing of the Pandavas, but she had never allowed her role as a wife to devour her own individuality and her own existence. And she knew how to raise her self- esteem by recollecting her achievements amidst the adversities of her life, "I'd played a crucial role in bringing them to their destiny. I'd shared their hardship in Khandav. I'd helped them design this unique palace, which so many longed to see. If they were pearls, I was the gold wire onwhich they were strung" (Divakaruni 151). Draupadi by admiring her own individuality and her own uniqueness had rejected the prevailing baseless prejudices regarding women's 
life on earth. Through the opinions of Dhri's tutor, women's stature in the society of their age was clearly revealed. Draupadi said, "Dhri's tutor was of the opinion that virtuous women were sent directly into their next birth, where, if they were lucky, they reincarnated as men. But I thought that if lokas existed at all, good women would surely go to one where men were not allowed so that they could be finally free of male demands" (Divakaruni 155). These words of Draupadi were enough to prove her resistance against the patriarchal domination, and by expecting the existence of such a world she had reflected her own hope to attain the desired freedom and satisfaction.

Draupadi also expressed her dissention from Yudhishthira's beliefs and ideals, because she could not understand how he could show such obedience and gratitude for Dhritarashtra, the king of Hastinapur, who had once conspired to kill all the Pandavas. Draupadi from her childhood had never learned to favor those people who were not worthy of that, even she could not forgive her father king Draupad also, as she said that she could not forget her father's initial rejection of herself. Draupadi's anger towards Dhritarashtra can be observed clearly when she said, "He blessed me also with such platitudes as may you be the mother of a hundred sons, or May your wedding sindura forever shine on your forehead. (We knew, of course, that he'd like nothing better than to have the entire Pandavalineage perish)" (Divakaruni 129). Dhritarashtra's compassionate and caring words for the pandavas and for herself had always surprised her, and also compelled her to question Dhritarashtra's deceptive dual attitudes towards them, and she speculated in her mind, "Was he a saint, or merely lacking in common sense?” (Divakaruni 129).

When, Duryodhana ordered to drag Draupadi to the court, then Draupadi's wit puzzled all the wise men at the court and they could not answer Draupadi's question. She asked Yudhishthira, about who was staked first, because if Yudhishthira had staked himself first and he had lost himself in the dice, then he could not stake her, because he had already 
lost his right over her. She recalled about the Nyaya Shastra to assert the veracity of her claim, according to Nyaya Shastra, she said, "If perchance a man lost himself, he no longer had any jurisdiction over his wife" (Divakaruni190). She thought that the wise men of Hastinapur could not contradict the Nyaya Shastra, but she was mistaken, and Dussasan dragged her to the court. Draupadi's humiliation was enough to claim that, in a patriarchal society, the concept of 'dharma' or justice is itself biased, which men can use, change and create according to their own will. Even the shastras and scriptures are only used as the tools to appease their own dominant policies. Draupadi had tried everything to save her dignity, but she could not, and she was insulted and humiliated. Draupadi, who was also known as Yajnaseni, the lady who was emerged from the sacred fire, was aware of her own divinity, and she knew very well that she was here on earth to bring change for a better future. Though she was alone at the court, despite the presence of her husbands, she had not lost her courage and she addressed the Kauravas furiously, "All of you will die in the battle that will be spawned from this day's work. Your mothers and wives will weep far more piteously than I've wept. This entire kingdom will become a charnel house. Not one Kaurava heir will be left to offer prayers for the dead. All that will remain is the shameful memory of today, what you tried to do to a defenseless woman" (Divakaruni 194). She again said, "I will not comb it,' I said, 'until the day I bathe it in Kaurava blood"” (Divakaruni 194). She had promised herself that she would avenge her own humiliation, and she had done this by influencing the invincible Pandavas to fight for justice, and as Kshatriya princes, it was their duty towards the society and they could not ignore their responsibility.Divakaruni'sDraupadididn't choose to remain silent, but she had chosen revenge, and it was Yajnaseni's fire of revenge which destroyed the whole Kaurava clan.

Draupadi pondered over her own existence as a woman in their society, "I'm a queen, Daughter of king Draupad, sister of Dhrishtadyumna, Mistress of the greatest palace on earth. 
I can't be gambled away like a bag of coins, or summoned to court like a dancing girl" (Divakaruni 190). Through these words Draupadi not only expressing her own resentment for the injustices done to her, but indirectly she was also highlighting the plight of those women who didn't belong to the royal families, because, even her royalty could not save her dignity, then what would women of ordinary birth could expect. When she decided to renounce the worldly life with the Pandavas, then everyone around her including her husbands advised her to stay back. But Draupadi had already made her mind for that and she became the first woman to attempt this. Draupadi said, "The more people dissuaded me, the more determined I became. Perhaps that has always been my problem, to rebel against the boundaries society has prescribed for women" (Divakaruni 343). Draupadi knew very well that besides Yudhishthira, all of them would die on the mountain, but as a strong woman she had never learnt to fear death, what disturbed her during their journey through the Himalayas, was the fear of failure. Because, their failure in reaching their divine destination would be considered as the moral failure and not the physical. At the last moment of her life, with Krishna's blessing, she got that, for what she longed throughout her life, and she said, "At his touch something breaks, a chain that was tied to the woman-shape crumbled on the snow below. I am buoyant and expansive and uncontainable_-but I always was so, only I never knew it! I am beyond name and gender and the imprisoning patterns of ego" (Divakaruni 360). In this way, Draupadi had fulfilled her journey for freedom and this freedom had rescued her true identity.

Patriarchal ideology defines women as the inferior beings or the 'other' of the society. Draupadi was also taught to live as the shadow of her husbands, which implies that she must stand behind her husbands in all the circumstances and she had to follow their each and every command blindly, because, they were her mentors and guides, and her duty was to obey their expectations and follow their path. But Draupadi with her strong determination and 
indomitable courage, reversed the prevailing belief regarding women's existence. By influencing the Pandavas to stay on the path of dharma, she herself became their mentor and the source of their strength, and in this way, she played the vital role in intensifying the victory of justice.

Conclusion

Divakaruni in her The Palace of Illusions not only explored the unheard voice of Draupadi but in this way she had also recreated Draupadi's identity. In presenting Draupadi's character Divakaruni, very tactfully blended the contemporary issues related to women in the countries like India. Though Draupadi belonged to the ancient age and to a forgotten society, but ironically the issues related to women have not much changed till date. Women from different regions of our country still struggling for education and fighting for their rights.The Palace Illusions by Divakaruni also can be considered as an attempt to criticize the baseless gender prejudices prevalent in our society, claiming the necessity to bring change. 


\section{Works Cited}

Barry, Peter. BeginningTheory. New Delhi: Viva Books Private Limited, 2018. Print.

Beauvoir, Simon De. TheSecondSex. London: Vintage, 1989. Print.

Cixous, Helen. “The Laugh of the Medusa: New French Feminism”. FeministLiterary

Theory.Ed. Mary Eagleton. Oxford: Blackwell, 1986. 245-64. Print.

Divakaruni, Chitra Banerjee. ThePalaceofIllusions. New York: Picador, 2008. Print.

Friedan, Betty. TheFeminineMystique. United States: WW Norton \& Co.,1963.Print.

Nayar, Pramod K. ContemporaryLiteraryandCulturalTheory: FromStructuralismto Ecocriticism. Delhi: Pearson, 2009.Print.

Tyson, Lois. CriticalTheoryToday. New York: Routledge, 2006. Print. 